\title{
Right to Choose within CEDAW: It's Importance to Women in Nigeria.
}

\author{
Ganiat Mobolaji Olatokun \\ School of Law, College of Law, Government and International Studies, Universiti Utara Malaysia.
}

\begin{abstract}
The right to choose for women is an important provisions contained in the Convention on the Elimination of all forms of Discrimination against Women (CEDAW). This provision embodies power for Nigerian women. This article intends to showcase the importance of the right to choose to Nigerian women. A case study was carried out in eight (8) different states in Nigeria, and the result reveals that, most people in Nigeria look up to the right to choose within CEDAW as a very important and vital provision for Nigerian women, if they are to live up to their worth as women, for within this provision, health for all women is guaranteed, economic hardship will be reduced and above all, women will have the weapon to decide for themselves.
\end{abstract}

Keywords: CEDAW, health, Nigeria, right to choose, women.

\section{Introduction}

The total population of Nigeria as a country stands at, $174,505,539$ people as at $2013 .{ }^{1}$ Out of this number, women constitute $86,928,840 .^{2}$ In a country with such number of women, it is expected that the government of that country ought to pay particular attention to issues affecting the women folks. One of such issues is the right to choose provisions contained in the Convention on the Elimination of all Discrimination against Women (CEDAW). ${ }^{3}$ Sadly, this Convention is yet to be domesticated and implemented in Nigeria, ${ }^{4}$ revealing that, Nigerian women are likely to be denied of three things which basically can be guaranteed by the right to choose as contained within CEDAW. Firstly, Nigerian women will be denied of the right to decide what to do with their bodies, ${ }^{5}$ in that, they will be denied of the right to choose to determine the timing of their pregnancies. ${ }^{6}$ Secondly, Nigerian women are likely to be denied of the right to health, in that, failure to be able to determine the right timing of pregnancies is injurious to both mother and the unborn child. ${ }^{7}$ Lastly, the Nigerian women are likely to be robbed of the opportunity of being self determined in that, women in Nigeria will not have the opportunity to decide for themselves on issues of maternity. ${ }^{8}$ Aside these, the right to choose provision contained in CEDAW is capable of reducing the economic hardship presently faced in Nigeria to the barest minimum. ${ }^{9}$

This paper will serve as an eye opener to the generality of people in Nigeria, and to the Nigerian government in particular, that the right to choose provision within CEDAW is a laudable venture and its importance will be felt more when the government proceed to domesticate and subsequently implement CEDAW. This paper is a deviation from the previous works, calling on Nigerian government to domesticate and

\footnotetext{
${ }^{1}$ Nigeria Demographics Profile, 2013.<http://www.indexmundi.com/nigeria/demographics_profile.html〉 (accessed: December 16,2013): geoba.se Nigeria. http://www.geoba.se/country.php?cc=NG (accessed: December 16, 2013).

${ }^{2}$ geoba.se Nigeria. http://www.geoba.se/country.php?cc=NG (accessed: December 16, 2013).

${ }^{3}$ A women Convention which was adopted by the UN in 1979.

${ }^{4}$ Nigeria ratified CEDAW since 1985 and up till present, the country is yet to implement the Convention.

${ }^{5}$ The right to determine what women do with their bodies as used in this paper is very different from the western idea of determining what to do with the body. The Western idea of body sensitivity has been linked to female inequality brought about by female biology. See, S. Firestone, The Dialectic of Sex: The Case for Feminist Revolution, New York: Farrar, Straus and Giroux, 2003, pp. 8-12. Also, western idea of determining what women do with their body has been linked to gaining the access to safe and legal abortion, which finally allowed women to have the basic right of controlling their own bodies. P. Smith, "Feminist Philosophy of Law" Stanford Encyclopedia of Philosophy 2009 http://plato.stanford.edu/entries/feminism-law/ (accessed June15, 2012).

${ }^{6}$ The timing of pregnancy as used in this paper refers to determining the number and spacing of children, as used within the Article 16 of CEDAW.

${ }^{7}$ Amy O. Tsui, Raegan McDonald-Mosley and Anne E. Burke, "Family planning and the burden of Unintended Pregnancies" Oxford Journals Epidemiological Review 32, No.1 (2010): 152, http://epirev.oxfordjournals.org/content/32/1/152.full (accessed June 25, 2012). ${ }^{8}$ Mustapha Duze and Ismaila Mohammed, "Male Knowledge, Attitudes and Family Planning Practices in Northern Nigeria" African Journal of Reproductive Health 10, No.3 (2006): 55, http://www.ajol.info/index.php/ajrh/article/viewFile/7899/13886 (accessed June 24, 2012) ${ }^{9}$ Women have expressed the view that because of economy, they wanted to get pregnant later, wanted fewer children, or now did not want any more children. See, Rachel Benson Gold, "Recession Taking its Toll: Family Planning Safety Net Stretched Thin as Service Demand Increase" Guttmacher Policy Review, 13(1), (2010). http://www.guttmacher.org/pubs/gpr/13/1/gpr130810.html (accessed December 16, 2013).
} 
implement CEDAW because; it is a Convention focusing on women. ${ }^{10}$ This paper on the other hand, is calling on the Nigerian government to domesticate and implement CEDAW not only because it is a women Convention, but because of the content of CEDAW, basically, the right to choose which encompasses health and determination for women who are the mothers of the nation. ${ }^{11}$

\section{Right to Choose}

It is important to state from the start that, the Universal Declaration of Human Rights has shown considerable interests in equal rights of men and women ${ }^{12}$ specifically under the minority and group rights. Women, being classified as a minority group therefore, enjoy special considerations, and rights affecting them are given high priority. Consequently, the General Assembly of the United Nations, on the $18^{\text {th }}$ December 1979 , adopted the Convention on the Elimination of all forms of Discrimination against Women, CEDAW. The Convention is a human right document which promotes the principle of non-discrimination and equality between men and women. The Convention focuses on three key issues of which reproductive right is one. The right to choose is one aspect of reproductive right.

Other aspects of reproductive rights includes, fully shared responsibility for child rearing by both sexes and right to maternity and family planning. Reproductive rights under CEDAW are contained in Article 12 dealing with health and Article 16 dealing with marriage and family. Article 12 provides;

'States parties shall take all appropriate measures to eliminate discrimination against women in the field of health care in order to ensure, on the basis of equality of men and women, access to health services, including those related to family planning'

Reading the Convention further, Article 16(1) (e) provides:

'State parties shall take all appropriate measures to eliminate discrimination against women in all matters relating to marriage and family relations and in particular shall ensure, on the basis of equality of men and women; the same rights to decide freely and responsibly on the number and spacing of their children and to have access to the information, education and means to enable them exercise these rights'

The combined effect of these articles is that, in order for the good health of women; women should be able to decide freely and responsibly as regards the number and spacing of their children. ${ }^{13}$ The importance of the right to choose within CEDAW cannot be overlooked and the failure of the Nigerian government to implement CEDAW on the grounds that the right to choose confers abortion right ${ }^{14}$ to women cannot hold water, because going by the recent concluded study, the majority of participants do not look at CEDAW as giving right to abort.

Nigeria ratified the Convention on the Elimination of all forms of Discrimination against women (CEDAW) in 1985. Up till date, the government of the country has neither documented nor implemented the Convention. The reason being that most people in Nigeria fear that the 'right to choose' within CEDAW is synonymous to abortion right for women. However, an empirical analysis was carried out in eight (8) different states in Nigeria, sampling the opinions of people on the importance of 'right to choose' within CEDAW. In the whole of the discussion with the participants of the study, neither abortion nor abortion right featured in their different opinions. The empirical study revealed that most of the participants looked up to the 'right to choose' within CEDAW as very important for women in Nigeria because it will afford women the opportunity to space their children. This implies giving adequate time within births of children.

\section{Methodology}

Rather than select a large number of people, the qualitative researcher, like this author identifies and recruits a small number of samples that will provide in depth information about the central phenomenon. A qualitative sampling is a non-probability sampling. The type of non-probability sampling that was employed in

\footnotetext{
${ }^{10}$ A Shadow Report (2008), “CEDAW and Accountability to Gender Equality in Nigeria” http://www.ng.boell.org/web/gender-199.html (accessed: December 16, 2013); 'Because female legislators are few, their voices are always drowned. That is why we're appealing to gender-responsive male legislators to please domesticate CEDAW'. See, Josephine Igbinove, "Nigeria is Notorious for Abandoning International Treaties- Oby Nwankwo", Vanguard Online Newspaper, September 22, 2013. http://www.vanguardngr.com/2013/09/nigeriais-notorious-for-abandoning-international-treaties-oby-nwankwo/ (accessed: December 16, 2013).

${ }^{11}$ This work has showcased that when women are healthy, they will give birth to healthy children, making up a healthy nation. In the long run, it brings us to a popular adage in Nigeria which says that, 'health is wealth'.

${ }^{12}$ Article 2 of the Universal Declaration of Human Rights (1948); Devaki Jain, Women, Development and UN: A Sixty-Year Quest for Equality and Justice, (Bloomington USA: Indiana University Press, 2005), 11-12; Christopher McCrudden, "Human Dignity and Judicial Interpretation of Human Rights" European Journal of International Law 19, no. 4 (2008): 655. http://www.ejil.org/pdfs/19/4/1658.pdf (accessed November 25, 2011).

${ }^{13}$ The World Health Organization has described birth spacing as a procedure which save lives of mothers and babies, reduces abortion and unwanted pregnancies and improves children's health and mother's health. The World Health Organization, Birth Spacing Cluster Representatives and Health Volunteers Guide (2008) 2-3 www.emro.who.int/mps/pdf (accessed November 26, 2011).

${ }^{14} \mathrm{This}$ is a western perspective. See note 5 above.
} 
this study is the purposeful or judgment sampling. While using this sampling method, the author purposely choose subjects who, in her opinion, are thought to be relevant to the research topic. In this way, the author uses her own judgment as to who can provide the best information to achieve the objective of the study. ${ }^{15}$

In a purposeful sampling, random sampling makes little sense. ${ }^{16}$ The author is not interested in 'how much' or 'how often'. It is therefore, necessary to select samples from which most can be learned. This study is interested in understanding a phenomenon of interest which lies in the views of certain social actors on the right to choose and its importance to Nigerian women. The author sampled for heterogeneity, ${ }^{17}$ where all relevant opinions and views will be included. The author is not concerned about representing the views proportionally, because their primary aim is getting broad spectrum of ideas, not identifying 'average' or 'modal instance'. Here, what were sampled are not the people, but their ideas and opinions.

It has been imagined that, there is a universe of all possible ideas relevant to the topic, and the author, in order to sample these ideas, have included a broad and diverse range of participants, including the 'outliers' or unusual ones in order to get the ideas required. Having regards to the fact that, different people view things differently, the author used her judgment in choosing participants for this study. These participants include; nongovernmental organizations concerning women, League of Moslem and Christian Women, African Traditionalists, Medical Practitioners, Married and Unmarried men and women.

The reason for these choices of participants is that, the non-governmental organizations and the religious league are most concerned about women, and since this study is a women issue, their opinion was thought as relevant. The opinion of African traditionalist is of importance because, Nigeria is an African setting with well known tradition and values attached to women. The African traditionalists were able to give the importance of 'right to choose' within CEDAW from a traditional perspective. Looking at it from a medical perspective, the medical practitioners in this study were able to provide the importance of 'right to choose' within CEDAW. For the single fact that the issue under discourse pertains to women, both married and unmarried women were able to express their views on the importance of 'right to choose' within CEDAW. Lastly, the choices of the married and unmarried men are not farfetched. The men are connected to women either as husbands or as boyfriends.

Qualitative research is very labour intensive. Analyzing a large sample can be time consuming and often impractical. ${ }^{18}$ Thus, ' 15 ' has been said to be the smallest acceptable sample for all qualitative research. ${ }^{19}$ However, Charmaz ${ }^{20}$ has suggested that ' 25 ' participants are adequate for small project and according to Ritchie et al, ${ }^{21}$ qualitative samples often lie under ' 50 '. 'Experience of most qualitative researchers (emphasis added) is that, in interview studies, little that is 'new' comes out of transcripts after you have interviewed 20 or so people.

Ultimately, the author secured 21 Key informants and 2 focus group sessions (the focus group ' 1 ' comprised of four participants, while the focus group ' 2 ' comprise of six participants) ${ }^{23}$ consisting of both Christians and Moslems. They came from various backgrounds and professions, had varying qualifications and worked in both government as well as non-government organizations.

\footnotetext{
${ }^{15}$ Kumar R., Research Methodology: a step by step Guide for Beginners (London, California, India: Sage Publications, 1996), 162; Sarantakos S., Social Research (Basingstoke: Macmillan Press, 1998), 152

${ }^{16}$ Donald E. Pokinghorne, "Language and Meaning: Data Collection in Qualitative Research" Journal of Counseling Psychology 52, No.2 (2005):

http://csuphd.pbworks.com/w/file/fetch/47745393/Polkinghorne_Language\%20and\%20Meaning\%20data\%20collection\%20in\%20qr.pdf (accessed January 22, 2012). Random sampling, which is a form of probability sampling, is not necessary or even justifiable in a qualitative research. Merriam S B, Qualitative Research and Case Study Applications in Education, (Sanfrancisco: Jossey- Bass Publishers, 1998$), 61$. ${ }^{17}$ William M. K. Trochim, "Non-Probability Sampling Research Methods Knowledge Base” Web Center for social Research Method. Last Revised $20^{\text {th }}$ October 2006. http://www.socialresearchmethods.net/kb/sampnon.php (accessed February 10, 2012).

${ }^{18}$ Mason Mark, "Sampling and Saturation in PhD Studies Using Qualitative Interviews" Forum Qualitative Sozialforschung/Forum: Qualitative Social Research 11, No.3 Art 8(2010), http://www.qualitative-research.net/index.php/fqs/article/view/1428/3027 (accessed February 23, 2012).

${ }^{19}$ Bertaux Daniel, "From the Life-History Approach to the Transformation of Sociological Practice" in Biography and Society: The Life History Approach in the Social Sciences ed. Daniel Bertaux (London, California, India: Sage Publications, 1981), 35.

${ }^{20}$ Charmz Kathy, Constructing Grounded Theory: A Practical Guide Through Qualitative Analysis (London, California, India: Sage Publications, 2006), 114.

${ }^{21}$ Ritchie Jane, Lewis Jane and Ellam Gillian, "Designing and Selecting Samples" in Qualitative Research Practice. A Guide for Social Science Students and Reserachers eds. Jane Ritchie and Jane Lewis (London, California, India: Sage Publications, 2003), 84.

${ }^{22}$ Green Judith and Thorogood Nicki, Qualitative Methods for Health Research (London, California, India: Sage Publications, 2009 ), 120.

${ }^{23}$ Focus group interview is an interview with a small group of people on a specific topic. Groups are typically 6 to 10 people with similar background who participate in the interview for one or two hours. Patton Michael Quinn, Qualitative Research and Evaluation Methods $3^{\text {rd }}$ Edition (London, California, India: Sage Publications Inc, 2002). 385.
} 


\subsection{Participant's Background}

\subsubsection{Table 1: Background Information of Key Informants}

\begin{tabular}{|c|c|c|c|c|c|c|}
\hline & Study Areas & Occupation & Education & Religion & Sex & Unit of Analysis \\
\hline KI1 & Ilorin & Politician & MBBS & Islam & $\mathrm{M}$ & Doctors \\
\hline KI2 & Ajaokuta & Orthodox Doctor & MBBS & Christianity & $\bar{M}$ & Doctor \\
\hline KI3 & Lokoja & Orthodox Doctor & MBBS & Christianity & $\bar{F}$ & Doctor \\
\hline KI4 & Ilorin & $\begin{array}{l}\text { Retired Civil } \\
\text { Servant }\end{array}$ & Diploma & Christianity & $\bar{M}$ & Married Man \\
\hline KI5 & Ilorin & Islamic Cleric & $\begin{array}{l}\text { Primary } \\
\text { School } \\
\text { Certificate }\end{array}$ & Islam & M & Married Man \\
\hline KI6 & Abuja & Banker & B.sc & Islam & $\mathrm{M}$ & Married Man \\
\hline KI7 & Ilorin & Trader & B.sc & Islam & $\mathrm{F}$ & Married Woman \\
\hline KI8 & Lokoja & Nurse & $\begin{array}{l}\text { School } \\
\text { Nursing } \\
\text { Certificate }\end{array}$ & Christianity & $\mathrm{F}$ & Married Woman \\
\hline KI9 & Ajaokuta & $\begin{array}{l}\text { Hospital } \\
\text { Attendant }\end{array}$ & $\begin{array}{l}\text { Primary } \\
\text { School } \\
\text { Certificate }\end{array}$ & Christianity & F & Married Woman \\
\hline KI10 & Lagos & Student & Student & Islam & $\bar{M}$ & Unmarried Man \\
\hline KI11 & Ilorin & Banker & $\mathrm{BA}$ & Christianity & M & Unmarried Man \\
\hline KI12 & Lokoja & Civil Servant & $\overline{\mathrm{BA}}$ & Islam & $\bar{M}$ & Unmarried Man \\
\hline KI13 & Abuja & Teacher & $\begin{array}{l}\text { National } \\
\text { Certificate of } \\
\text { Education }\end{array}$ & Christianity & $\mathrm{F}$ & Unmarried Woman \\
\hline KI14 & Abuja & Civil Servant & Diploma & Christianity & $\mathrm{F}$ & Unmarried Woman \\
\hline KI15 & Ilorin & Student & Student & Islam & $\mathrm{F}$ & Unmarried Woman \\
\hline KI16 & Abuja & NGO Director & B.sc & Islam & $\mathrm{F}$ & $\begin{array}{l}\text { (Dawah)Non- } \\
\text { Governmental } \\
\text { Organization }\end{array}$ \\
\hline KI17 & Ilorin & $\begin{array}{l}\text { Nursery and } \\
\text { Primary School } \\
\text { Proprietress }\end{array}$ & B.sc & Christianity & $\mathrm{F}$ & $\begin{array}{l}\text { (Girls' Guide)Non- } \\
\text { Governmental } \\
\text { Organization }\end{array}$ \\
\hline KI18 & Abuja & $\begin{array}{l}\text { Secretary FIDA } \\
\text { Office }\end{array}$ & LL.B, BL & Christianity & $\mathrm{F}$ & $\begin{array}{l}\text { (FIDA) Non- } \\
\text { Governmental } \\
\text { Organization }\end{array}$ \\
\hline KI19 & Ilesha & NGO Director & Pharmacist & Christianity & F & $\begin{array}{l}\text { (Disabled Children) } \\
\text { Non-Governmental } \\
\text { Organization }\end{array}$ \\
\hline KI20 & Ile-Ife & $\begin{array}{l}\text { Senior Lecturer, } \\
\text { Obafemi } \\
\text { Awolowo } \\
\text { University. Ile- } \\
\text { Ife }\end{array}$ & $\mathrm{PhD}$ & Christianity & $\bar{M}$ & $\begin{array}{l}\text { African Traditional } \\
\text { Religion }\end{array}$ \\
\hline KI 21 & Osogbo & $\begin{array}{l}\text { International } \\
\text { Renowned author } \\
\text { and Chief Priest }\end{array}$ & …........ & Traditionalist & M & $\begin{array}{l}\text { African Traditional } \\
\text { Religion }\end{array}$ \\
\hline
\end{tabular}

- Source: Field Study 2012

- KI: Key Informants

3.1.2 Table 2: Background Information of Focus Group Session '1'

\begin{tabular}{|c|c|c|c|c|c|c|}
\hline & Study Area & Occupation & Education & Religion & Sex & Unit of Analysis \\
\hline FGS1a & Ilorin & Nurse & $\begin{array}{l}\text { School of } \\
\text { Nursing } \\
\text { Certificate }\end{array}$ & Christianity & $\mathrm{F}$ & $\begin{array}{l}\text { Women Wing of } \\
\text { Christian } \\
\text { Association of } \\
\text { Nigeria (CAN) }\end{array}$ \\
\hline FGS1b & Ilorin & $\begin{array}{l}\text { Headmistress of } \\
\text { Public School }\end{array}$ & $\begin{array}{l}\text { National } \\
\text { Certificate of } \\
\text { Education }\end{array}$ & Christianity & $\mathrm{F}$ & $\begin{array}{l}\text { Women Wing of } \\
\text { Christian } \\
\text { Association of } \\
\text { Nigeria (CAN) }\end{array}$ \\
\hline FGS1c & Ilorin & Trader & $\begin{array}{l}\text { Secondary } \\
\text { School } \\
\text { Certificate }\end{array}$ & Christianity & $\mathrm{F}$ & $\begin{array}{l}\text { Women Wing of } \\
\text { Christian } \\
\text { Association of } \\
\text { Nigeria (CAN) }\end{array}$ \\
\hline FGS1d & Ilorin & $\begin{array}{l}\text { Secretary } \\
\text { Women Wing of } \\
\text { Christian } \\
\text { Association of } \\
\text { Nigeria }\end{array}$ & B.sc & Christianity & $\mathrm{F}$ & $\begin{array}{l}\text { Women Wing of } \\
\text { Christian } \\
\text { Association of } \\
\text { Nigeria (CAN) }\end{array}$ \\
\hline
\end{tabular}


- Source: Field Study 2012

- FGS: Focus group session

\subsubsection{Table 3: Background Information Focus Group Session '2'}

\begin{tabular}{|c|c|c|c|c|c|c|}
\hline & Study Area & Occupation & Education & Religion & Sex & Unit of Analysis \\
\hline FGS2a & Ilorin & $\begin{array}{l}\text { National Trustee } \\
\text { of FOMWAN } \\
\text { and Proprietor of } \\
\text { Secondary } \\
\text { School }\end{array}$ & $\mathrm{BA}$ & Islam & $\mathrm{F}$ & $\begin{array}{l}\text { Federation of Muslim } \\
\text { Women Organization } \\
\text { of Nigeria (FOMWAN) }\end{array}$ \\
\hline FGS2b & Ilorin & Teacher & $\begin{array}{l}\text { National } \\
\text { Certificate of } \\
\text { Education }\end{array}$ & Islam & $\mathrm{F}$ & $\begin{array}{l}\text { Federation of Muslim } \\
\text { Women Organization } \\
\text { of Nigeria (FOMWAN) }\end{array}$ \\
\hline FDS2c & Ilorin & $\begin{array}{l}\text { Business } \\
\text { Woman }\end{array}$ & $\begin{array}{l}\text { Secondary } \\
\text { School } \\
\text { certificate }\end{array}$ & Islam & $\mathrm{F}$ & $\begin{array}{l}\text { Federation of Muslim } \\
\text { Women Organization } \\
\text { of Nigeria (FOMWAN) }\end{array}$ \\
\hline FGD2d & Ilorin & Civil Servant & B.sc & Islam & $\mathrm{F}$ & $\begin{array}{l}\text { Federation of Muslim } \\
\text { Women Organization } \\
\text { of Nigeria (FOMWAN) }\end{array}$ \\
\hline FGS2e & Ilorin & Civil Servant & B.sc & Islam & $\mathrm{F}$ & $\begin{array}{l}\text { Federation of Muslim } \\
\text { Women Organization } \\
\text { of Nigeria (FOMWAN) }\end{array}$ \\
\hline FGS2f & Ilorin & Trader & $\begin{array}{l}\text { Primary School } \\
\text { Certificate }\end{array}$ & Islam & $\mathrm{F}$ & $\begin{array}{l}\text { Federation of Muslim } \\
\text { Women Organization } \\
\text { (FOMWAN) }\end{array}$ \\
\hline
\end{tabular}

- Source: Field 2012

- FGS: Focus group session

\section{Findings and Discussion}

The contemporary nature of the topic under discourse arouses a lot of concern amongst several people in Nigeria. Consequently, the author did not find it difficult to persuade people to participate in the study. During the period of data collection, from $1^{\text {st }}$ March 2012 to May $15^{\text {th }} 2012$, several meetings took place with various participants at different times and venues depending on the convenience of the participants. ${ }^{24}$ The participants were most helpful in this regard. While the focus group participants volunteered the venues for the discussion, ${ }^{25}$ the individual participants gave appointments, fixing the venue at their various places of work, and even homes. ${ }^{26}$ Engaging various participants in this study is very helpful in order to know the importance of 'right to choose' within CEDAW to women of Nigeria.

The manual thematic analysis used in this study reveals that most of the participants consider 'right to choose' within CEDAW to be important for the Nigerian women basically on the grounds of health (mother and child's health) and economic hardship in the country. Be that as it may, further analysis shows that, some participants consider the right to choose as important for the Nigerian women, if they have to assume the position of deciding for themselves. The results of the findings are hereunder discussed;

\subsection{Child Spacing and Health}

The benefits of pregnancy planning and child spacing on maternal, infant and child health has been well documented. Research have shown that family planning can reduce about $25 \%$ to $40 \%$ maternal deaths by preventing unplanned and unwanted pregnancies and about $10 \%$ of child deaths by eliminating inter-birth intervals of less than two years. ${ }^{27}$

\footnotetext{
${ }^{24}$ The participants that took part in the study lived across eight towns within Nigeria namely, Ilorin, Ile-Ife, Osogbo, Ilesha, Lokoja, Ajaokuta, Lagos and the Federal Capital Territory, Abuja. These towns can conveniently be distributed within five different States within the country namely, Kwara State (Ilorin), Osun State (Ile-Ife, Osogbo and Ilesha), Kogi State (Lokoja and Ajaokuta), Lagos State (Lagos) and FCT (Abuja). The choice of location is further to ensure heterogeneity of views.

${ }^{25}$ Focus group 1, which is the Christian Association of Nigeria agreed to host the discussion at the residence of one of their leading members, situated at Sabo-Oke Area in Ilorin. The focus group 2, which is the Federation of Moslem Women of Nigeria, invited the researcher to be part of their Sunday program (Asalatu). Since the researcher is a Moslem herself, she finds it easy to blend with the proceedings at the program. After the Asalatu, the discussion started in earnest at the FOMWAN Secretariat situated at Murtala Mohammed Way, Ilorin. Kwara State. Nigeria.

${ }^{26}$ The offices, homes and business places of all the individual participants are situated in different places across these five States.

${ }^{27}$ Yohannes Dibaba, "Child Spacing and Fertility Planning Behavior among Women in Mana District, Jima Zone South West Ethiopia" Ethiopia Journal of Health Science 2, No.2 (2010): 84, http://www.ejhs.ju.edu.et/admin/Volume-20-Num2/Yohannes.pdf (accessed June 25, 2012).
} 
The impressive reductions in maternal deaths are similar to the effectiveness of such undisputed public health interventions as oral contraception. ${ }^{28}$ Family planning also contributes to birth spacing, lower infant mortality risks as well as lowering maternal mortality and maternal morbidity associated with unintended pregnancies. ${ }^{29}$ Family planning programs are initiated for the well being of mother and child. Infant mortality is determined by the preceding birth intervals. ${ }^{30}$

For many years, studies ${ }^{31}$ demonstrated that when mothers' space births at least two years apart, their children are more likely to survive and to be healthy. Infant spaced at least two years apart are also less likely to be premature, of low birth weight and be malnourished. ${ }^{32}$ Children born after short intervals between pregnancies are at increased risk of developing autism. The highest risk was associated with pregnancies less than one year. ${ }^{33}$

In recognition of the adverse outcomes associated with close child birth intervals, the World Health Organization (WHO 2005) recommended a two year waiting period after birth before the next pregnancy. ${ }^{34}$ Short inter birth intervals has also been associated with leukemia. ${ }^{35}$

Based on the facts above, majority of the participants express the view that the 'right to choose' within CEDAW is important basically on health grounds for both mother and child.

\subsection{Child spacing and women's decision}

In Nigeria, there is the desire to have many children, especially by men who are not very educated and are polygamists. Ideal family size (IFS) is a good indicator of men's attitude towards child bearing. The mean family size was higher among illiterates, Muslims and polygamists. ${ }^{36}$ Educated men tend to have small family size because they understand the financial implications of large family size, while the Christians adopts the oneman and one-wife rule, the family size here is relatively smaller so that, there will not be competition among wives as to who will produce the greater number of children. ${ }^{37}$ However, the ideal family size is 16 children among the Kanuris of Nigeria. Kanuri men are polygamous and can marry up to four wives in order to form a large family. ${ }^{38}$

While this is so, little regard is given to the feelings and wants of the women. Hence, the importance of the right to choose within CEDAW cannot be over emphasized when looked at from the direction of enabling the women to choose for themselves, the time and spacing of their children. ${ }^{39}$

${ }^{28}$ Campbell O. M. and Graham W. J, "Strategies for Reducing Maternal Mortality: Getting on with what Works" Lancet 368 (2006): 1284, http://www.plan.givewell.org/files/Cause1-2/+UNICEF/Lancet\%20Maternal\%20Mortality\%202.pdf (accessed June 25, 2012).

${ }^{29}$ Amy O. Tsui, Raegan McDonald-Mosley and Anne E. Burke, "Family planning and the burden of Unintended Pregnancies" Oxford Journals Epidemiological Review 32, No.1 (2010): 152, http://epirev.oxfordjournals.org/content/32/1/152.full (accessed June 25, 2012).

${ }^{30}$ Unnati Rani Saha and Arthur Van Soest, "Does Family Planning Reduce Infant Mortality? Evidence from Surveillance Data in Matlab, Bangladesh” Discussion Paper No 2012-019 (2012): 2, http://arno.uvt.nl/show.cgi?fid=122012 (accessed June 25, 2012).

${ }^{31}$ Rutstein S. O., "Effects of Preceding Birth Intervals on Neonatal, Infant and Under-Five Years Mortality and Nutritional Status in Developing Countries: Evidence from the Demographic and Health Survey" International Journal of Obstetrics Genecology 89, No.1 (2005): S7, http://www.ncbi.nlm.nih.gov/pubmed/15820369 (accessed June 26, 2012).

${ }^{32}$ The relationship between chronic malnutrition and birth spacing is statistically significant. There is a clear pattern of increasing chronic and general under nutrition as the birth interval is shorter. Syed Farid-ul-Hasnain, "Prevalence and Risk Factors for Stunting among Children under 5 Years: A Community Based Study from Jhangara Town, Dahu Sindh" Journal of Pakistan Medical Association. 60, No.1 (2010): 41, http://jpma.org.pk/full article text.php?article id=1899 (accessed June 26, 2012).

${ }^{33}$ Keely Cheslack-Postava, "Closely Spaced Pregnancies are associated with Increased Odds of Autism in California Sibling Births" Pediatrics 127, (2011): 246, http://www.pediatricsdigest.mobi/content/127/2/246.full.pdf+html (accessed June 26, 2012); Joan C. Chrisler, Reproductive Justice: A Global Concern (Santa Barbara: Praeger, 2012), 154. Pregnancy intervals of less than six months are associated with increased risk of pre-term births and low birth weight. Farwa Rizvi and Ahmad Khan, "Birth Spacing as a Health Intervention" Ann Pak Institute of Medical Science 7, No.3 (2011): 113-114, http://apims.net/Volumes/Vol73/Birth\%20Spacing\%20as\%20a\%20Health\%20Intervention.html (accessed June 26, 2012).

${ }^{34}$ Chrisler (note 33 above), p154.

${ }^{35}$ Cardwell C. R. et al, "Inter Birth Interval is Associated with Childhood Type 1 Diabetes" Pubmed 61, No.3 (2012): 702, http://www.ncbi.nlm.nih.gov/pubmed/22315303 (accessed June 26, 2012).

${ }^{36}$ O. O. Odu, K. T. I Ijadunola and D. B. Parakoyi, "Reproductive Behavior and Determinants of Fertility among Men in a Semi-Urban Nigerian Community" Journal of Community Medicine and Primary Health Care 17, No.1 (2005): 17, http://www.ajol.info/index.php/jcmphc/article/viewFile/32419/6084 (accessed June 24, 2012).

${ }^{37}$ Ibid

${ }^{38}$ Mairiga et al, "Sociological Factors Influencing Decision Making" African Journal of Primary Health Care \& Family Medicine, 2 No.1 (2010), http://www.phcfm.org/index.php/phcfm/article/view/94/85 (accessed June 12, 2012); See also, Akinrinola Bankole et al, "Barriers to Safe Motherhood in Nigeria" Guttmacher Institute (2009): 7, http://www.guttmacher.org/pubs/2009/05/28/MotherhoodNigeria.pdf (accessed June 27, 2012)

${ }^{39}$ The reality is that, in Nigeria, most women do not have a say in decision making that affect their reproductive health and capacity. In any government owned hospitals, women might not be able to obtain family planning services without the consent of their husbands. Most decisions to use contraceptives are influenced by men. Mustapha Duze and Ismaila Mohammed, "Male Knowledge, Attitudes and Family Planning Practices in Northern Nigeria" African Journal of Reproductive Health 10, No.3 (2006): 55, http://www.ajol.info/index.php/ajrh/article/viewFile/7899/13886 (accessed June 24, 2012); Ijadunola M. Y. et al, "Male Involvement in Family Planning Decision Making in Ile-Ife Osun State Nigeria" African Journal of Reproductive Health 14, No.4 (2010): 46, 
Nigeria, being a patrilineal society, where decision making on all aspects within the family is solely the responsibility of the men ${ }^{40}$ the right to choose within CEDAW is seen as a weapon in the hands of women to voice out their concern and wishes with regards to the time they want to have another child. Although women might not be able to achieve this totally, but at least, they will have a say in deciding the timing of their children. By so doing, the patriarchal nature of sole male decision making would have been broken. ${ }^{41}$

An exploratory study of women's role in reproductive decision making in Ekiti show that women in the State are increasingly taking active decisions on matters affecting their daily lives. More women than ever before believed that they could take decisions on family size, when to have a baby and choice of spacing period. Women are seen to have taken joint decision with their husbands in respect of child spacing. ${ }^{42}$

Reproductive health knowledge is important for women as a woman's health and well being, contraception as well as those of her family, may depend on her being able to delay her first child or space the birth of her children. ${ }^{43}$

\subsection{Child Spacing and Economic Hardship}

The post colonial state in Nigeria has been chagrin. It's small-pace movement towards a sustainable good governance and development is daunting as various measures employed to combat the soaring poverty ratio appears to have failed, failing or does not suffice. Arguably, the increased level of poverty in the country have been attributed to long military rule, corruption, fiscal indiscipline of expenditure, mismanagement and over reliance on a single commodity (oil) for export and domestic consumption. ${ }^{44}$

Poverty is a condition where an individual finds it extremely difficult to meet the basic and essential needs of life that differentiate him from animal. ${ }^{45}$ Poverty can thus, have a profound influence on the social, physical and developmental needs of children and families. ${ }^{46}$

It is against this backdrop that the participants in this study viewed child spacing and family planning within CEDAW as an important element. According to them, the right to choose provision which encompasses child spacing and family planning will afford them the opportunity of having the number of children they can cater for. This is also one of the questions of population policy in Nigeria. ${ }^{47}$

Majority of households are experiencing growing food insecurity. Eating fewer meals and smaller amount was commonly reported, with many families cutting down from eating three times to eating twice or

http://www.ajol.info/index.php/ajrh/article/viewFile/67833/55928 (accessed June 24, 2012); O. A. Adeleye et al, "Barriers and Knowledge of Benefits regarding Family Planning Methods among Women attending Antenatal Clinics in a Southern Nigerian Community" Asian Journal of Medical Sciences 2, No.4 (2010): 193, http://maxwellsci.com/print/ajms/v2-190-194.pdf (accessed June 25, 2012).

${ }^{40}$ Abidemi R. Asiyanbola, "Patriarchy, Male Dominance, the Role and Empowerment of Women in Nigeria" being a paper submitted for presentation as poster at the International Union for Scientific Study of Population (IUSSP/UIESP) XXV International Population Conference Tours, France 18-23, 2005. (2005): 12, http://demoscope.ru/weekly/knigi/tours 2005/papers/iussp2005s50005.pdf (accessed June 24, 2012). Patriarchy denies women access to and control over decision making. Titilayo Cordelia Orisaremi and Ogoh Alubo, "Gender and Reproductive Rights of Tarok Women in Central Nigeria" African Journal of Reproductive Health 16, No.1 (2012): 84, http://www.ajol.info/index.php/ajrh/article/viewFile/75952/66444 (accessed June 24, 2012).

${ }^{41}$ I. O. Orubuloye, F. Oguntimehin and T. Sadiq, "Women's Role in Reproductive Health Decision Making and Vulnerability to STD and HIV/AIDS in Ekiti, Nigeria" Health Transition Review Supplementary to 7, (1997): 329 and 331, http://htc.anu.edu.au/pdfs/Orubulo8.pdf (accessed June 24, 2012)

${ }^{42} \mathrm{Ibid}$.

${ }^{43}$ O. A. Moronkola, M. M. Ojediran and A. Amosu, "Reproductive Health Knowledge, Beleifs and Determinants of Contraceptive Use among Women attending family Planning Clinics in Ibadan, Nigeria" African Health Sciences 6, No.3 (2006): 156, http://www.ncbi.nlm.nih.gov/pmc/articles/PMC1831883/pdf/AFHS0603-0155.pdf (accessed June 24, 2012).

${ }^{44}$ Jonathan S. Maiangwa, "An Overview of Pseudo-Therapeutic Approaches to Poverty in Nigeria" African Journal of Political Science and International Relations 3, No.9 (2009): 346. http://www.academicjournals.org/ajpsir/pdf/Pdf2009/September/Maiangwa.pdf (accessed June $25,2012)$.

${ }^{45}$ In a study area, $60 \%$ of the respondents earn less than $\# 10,000$ (RM200 emphasis mine) per month. This shows that, majority are living below poverty level. The household living conditions are correlated with violence and indications of socio-economic status. Majority live in one-room apartment and the average number of person per sleeping room are between 5-10 people. Demographic Health Survey (2003) explained that only $42 \%$ of Nigerians has access to clean water. The lack of sanitary facilities poses serious health problem, as majority of residents have no facility for sewage disposal. Adeyemi E. O et al, "Economic Reforms, Living Condition and Urban Violence: A Situation Report of Metropolitan Lagos" Ethiopian Journal of Environmental Studies and Management 2, No.2 (2009): 37 and 39 , http://www.ajol.info/index.php/ejesm/article/viewFile/45918/32325 (accessed June 25, 2012); UNITED NATIONS CHILDREN'S FUND (UNICEF), “The Nigerian Situation: 2007”, http://www.unicef.org/nigeria/1971_2199.html (accessed November 23, 2008).

${ }^{46}$ Rand D. Conger, "The Effect of Poverty and Economic Hardship across Generations" being a report prepared for California Department of Social Services (2005): 1, http://cppr.ucdavis.edu/pdf/poverty and hardship.pdf (accessed June 25, 2012).

${ }^{47}$ Helen Nene Avong, "Perception of and Attitudes Towards Nigerian Population Policy, Family Planning Program and Family Planning in Kaduna State Nigeria" African Reproductive Health 4, No.1 (2000): 67, http://www.ajol.info/index.php/ajrh/article/viewFile/7722/13856 (accessed June 25, 2012). 
even once a day. Women and children suffer disproportionately from food crisis. ${ }^{48}$ The recent removal of fuel subsidy by President Good Luck Jonathan of Nigeria has further led to the hick in price of all consumer goods transported by fuel. ${ }^{49}$

This being the case, some of the participants felt that it is no use bringing forth children into the world when they don't have the means of catering for them. Individuals who experience economic hardship will find it difficult paying bills or buying things the household needs such as food, clothing, medicine and medical care. ${ }^{50}$

\section{Conclusion}

The right to choose provision contained in the Convention on the Elimination of all forms of Discrimination against Women (CEDAW) has been shown to possess the access key to health for Nigerian women. If giving the opportunity, the right to choose within CEDAW can further guarantee for the Nigerian women, the power of autonomy to decide for themselves, the timing of their children. The right to choose within CEDAW can also serve as an engine for the reduction of economic hardship presently faced by the nation.

It is here asserted by the author that the ultimate challenge of the $21^{\text {st }}$ Century is for the government of the country to give preference to issues of women's right. This can only be done when the Nigerian government allows women to take advantage of the 'right to choose' within CEDAW. This, they can do, by domesticating and implementing the Convention on the Elimination of all forms of Discrimination against Women (CEDAW).

\section{References}

[1]. Nigeria Demographics Profile, 2013. <http://www.indexmundi.com/nigeria/demographics profile.html> (accessed: December 16,2013): geoba.se Nigeria. http://www.geoba.se/country.php?cc=NG (accessed: December 16, 2013).

[2]. geoba.se Nigeria. http://www.geoba.se/country.php?cc=NG (accessed: December 16, 2013).

[3]. Convention on the Elimination of All forms of Discrimination against Women 1979.

[4]. CEDAW ratification by Nigeria, 1985.

[5]. S. Firestone, The Dialectic of Sex: The Case for Feminist Revolution (New York: Farrar, Straus and Giroux, 2003); P. Smith, Feminist Philosophy of Law, Stanford Encyclopedia of Philosophy, 2009 http://plato.stanford.edu/entries/feminism-law/ (accessed June15, 2012).

[6]. Article 16 of CEDAW

[7]. Amy O. Tsui, Raegan McDonald-Mosley and Anne E. Burke, Family planning and the burden of Unintended Pregnancies, Oxford Journals Epidemiological Review 32(1), 2010, 152. http://epirev.oxfordjournals.org/content/32/1/152.full (accessed June 25, 2012).

[8]. Mustapha Duze and Ismaila Mohammed, Male Knowledge, Attitudes and Family Planning Practices in Northern Nigeria, African Journal of Reproductive Health 10(3), 2006, 55. http://www.ajol.info/index.php/ajrh/article/viewFile/7899/13886 (accessed June 24, 2012)

[9]. Rachel Benson Gold, Recession Taking its Toll: Family Planning Safety Net Stretched Thin as Service Demand Increase, Guttmacher Policy Review, 13(1), 2010. http://www.guttmacher.org/pubs/gpr/13/1/gpr130810.html (accessed December 16, 2013).

[10]. A Shadow Report, CEDAW and Accountability to Gender Equality in Nigeria, 2008. http://www.ng.boell.org/web/gender-199.html (accessed: December 16, 2013); Josephine Igbinove, Nigeria is Notorious for Abandoning International Treaties- Oby Nwankwo, Vanguard Online Newspaper, September 22, 2013. http://www.vanguardngr.com/2013/09/nigeria-is-notorious-for-abandoninginternational-treaties-oby-nwankwo/ (accessed: December 16, 2013).

[11]. G. M Olatokun, Field Work, 2012

[12]. Article 2 of the Universal Declaration of Human Rights (1948); Devaki Jain, Women, Development and UN: A Sixty-Year Quest for Equality and Justice, (Bloomington USA: Indiana University Press, 2005); Christopher McCrudden, Human Dignity and Judicial Interpretation of Human Rights, European Journal of International Law 19(4), 2008, 655. http://www.ejil.org/pdfs/19/4/1658.pdf (accessed November 25, 2011)

[13]. The World Health Organization, Birth Spacing Cluster Representatives and Health Volunteers Guide, 2008, 2-3 www.emro.who.int/mps/pdf (accessed November 26, 2011).

[14]. S. Firestone, "The Dialectic of Sex".

[15]. Kumar R., Research Methodology: a step by step Guide for Beginners (London, California, India: Sage Publications, 1996); Sarantakos S., Social Research (Basingstoke: Macmillan Press, 1998).

[16]. Donald E. Pokinghorne, Language and Meaning: Data Collection in Qualitative Research, Journal of Counseling Psychology 52(2), 2005 , http://csuphd.pbworks.com/w/file/fetch/47745393/Polkinghorne Language\%20and\%20Meaning\%20data\%20collection\%20in\%20 qr.pdf (accessed January 22, 2012); Merriam S B, Qualitative Research and Case Study Applications in Education, (Sanfrancisco: Jossey- Bass Publishers, 1998).

[17]. William M. K. Trochim, Non-Probability Sampling Research Methods Knowledge Base, Web Center for social Research Method. Last Revised $20^{\text {th }}$ October 2006. http://www.socialresearchmethods.net/kb/sampnon.php (accessed February 10, 2012).

[18]. Mason Mark, Sampling and Saturation in PhD Studies Using Qualitative Interviews, Forum Qualitative Sozialforschung/Forum: Qualitative Social Research 11(3), Art 8, 2010. http://www.qualitative-research.net/index.php/fqs/article/view/1428/3027 (accessed February 23, 2012).

\footnotetext{
${ }^{48}$ Fiona Samuels et al, "Food, Finance and Fuel: The Impact of the Triple F Crisis in Nigeria with Particular Focus on Women and Children" Overseas Development Institute (2011): 4-5, http://www.odi.org.uk/resources/docs/7359.pdf (accessed May 12, 2012)

${ }^{49}$ Anna Lekas Miller, "Occupy Nigeria: The Beginning of Sub-Saharan Awakening" Global Comments January 14, 2012, http://globalcomment.com/2012/occupy-nigeria-the-beginning-of-a-sub-saharan-awakening/ (accessed May 12, 2012).

${ }^{50}$ With increased resources, parents are able to invest in the development of their children, providing special care, time and services necessary to support their children's emotional needs. John Mirowsky and Catherine E. Ross, "Economic Hardship across the Life Course" American Sociological Review http://www.jstor.org/discover/10.2307/2657255?uid=3738672\&uid=2\&uid=4\&sid=21100870863291 (accessed June 25, 2012).
} 
[19]. Bertaux Daniel, "From the Life-History Approach to the Transformation of Sociological Practice" in Biography and Society: The Life History Approach in the Social Sciences ed. Daniel Bertaux (London, California, India: Sage Publications, 1981).

[20]. Charmz Kathy, Constructing Grounded Theory: A Practical Guide Through Qualitative Analysis (London, California, India: Sage Publications, 2006).

[21]. Ritchie Jane, Lewis Jane and Ellam Gillian, "Designing and Selecting Samples" in Qualitative Research Practice. A Guide for Social Science Students and Reserachers eds. Jane Ritchie and Jane Lewis (London, California, India: Sage Publications, 2003).

[22]. Green Judith and Thorogood Nicki, Qualitative Methods for Health Research (London, California, India: Sage Publications, 2009).

[23]. Patton Michael Quinn, Qualitative Research and Evaluation Methods $3^{\text {rd }}$ Edition (London, California, India: Sage Publications Inc, 2002).

[24]. Information about the participants that took part in this study.

[25]. Information about the Focus groups in this study.

[26]. Information about the field study.

[27]. Yohannes Dibaba, Child Spacing and Fertility Planning Behavior among Women in Mana District, Jima Zone South West Ethiopia, Ethiopia Journal of Health Science 2(2), 2010, 84. http://www.ejhs.ju.edu.et/admin/Volume-20-Num2/Yohannes.pdf (accessed June 25, 2012).

[28]. Campbell O. M. and Graham W. J, Strategies for Reducing Maternal Mortality: Getting on with what Works, Lancet 368, 2006, 1284. http://www.plan.givewell.org/files/Cause1-2/+UNICEF/Lancet\%20Maternal\%20Mortality\%202.pdf (accessed June 25, 2012).

[29]. Amy O. Tsui, Raegan McDonald-Mosley and Anne E. Burke, Family planning and the burden of Unintended Pregnancies, Oxford Journals Epidemiological Review 32(1), 2010, 152. http://epirev.oxfordjournals.org/content/32/1/152.full (accessed June 25, 2012).

[30]. Unnati Rani Saha and Arthur Van Soest, Does Family Planning Reduce Infant Mortality? Evidence from Surveillance Data in Matlab, Bangladesh, Discussion Paper No 2012-019, 2012, 2. http://arno.uvt.nl/show.cgi?fid=122012 (accessed June 25, 2012).

[31]. Rutstein S. O., Effects of Preceding Birth Intervals on Neonatal, Infant and Under-Five Years Mortality and Nutritional Status in Developing Countries: Evidence from the Demographic and Health Survey, International Journal of Obstetrics Genecology 89(1), 2005, S7. http://www.ncbi.nlm.nih.gov/pubmed/15820369 (accessed June 26, 2012).

[32]. Syed Farid-ul-Hasnain, Prevalence and Risk Factors for Stunting among Children under 5 Years: A Community Based Study from Jhangara Town, Dahu Sindh, Journal of Pakistan Medical Association. 60(1), 2010, 41. http://jpma.org.pk/full_article_text.php?article_id=1899 (accessed June 26, 2012).

[33]. Keely Cheslack-Postava, Closely Spaced Pregnancies are associated with Increased Odds of Autism in California Sibling Births, Pediatrics 127, 2011, 246. http://www.pediatricsdigest.mobi/content/127/2/246.full.pdf + html (accessed June 26, 2012); Joan C. Chrisler, Reproductive Justice: A Global Concern (Santa Barbara: Praeger, 2012); Farwa Rizvi and Ahmad Khan, Birth Spacing as a Health Intervention, Ann Pak Institute of Medical Science 7(3), 2011, 113-114. http://apims.net/Volumes/Vol73/Birth\%20Spacing\%20as\%20a\%20Health\%20Intervention.html (accessed June 26, 2012).

[34]. Joan C. Chrisler, Reproductive Justice, 154.

[35]. Cardwell C. R, Stevesson J, Waldhoer T, Ludviqson J, Sadauskaite-Kuehne V, Inter Birth Interval is Associated with Childhood Type 1 Diabetes, Pubmed 61(3) 2012, 702. http://www.ncbi.nlm.nih.gov/pubmed/22315303 (accessed June 26, 2012).

[36]. O. O. Odu, K. T. I Ijadunola and D. B. Parakoyi, Reproductive Behavior and Determinants of Fertility among Men in a Semi-Urban Nigerian Community, Journal of Community Medicine and Primary Health Care 17(1), 2005, 17. http://www.ajol.info/index.php/jcmphc/article/viewFile/32419/6084 (accessed June 24, 2012).

[37]. Ibid

[38]. Mairiga A. G, Kullima A. A, Bako B and Kolo M. A, Sociological Factors Influencing Decision Making, African Journal of Primary Health Care \& Family Medicine, 2(1), 2010, http://www.phcfm.org/index.php/phcfm/article/view/94/85 (accessed June 12, 2012); Akinrinola Bankole, Gilda Sedgh, Friday Okonofua, Collins Imarhiagbe, Rubina Hussain and Deirdre Wulf, Barriers to Safe Motherhood in Nigeria, Guttmacher Institute, 2009, 7. http://www.guttmacher.org/pubs/2009/05/28/MotherhoodNigeria.pdf (accessed June 27, 2012).

[39]. Mustapha Duze and Ismaila Mohammed, Male Knowledge, Attitudes and Family Planning Practices in Northern Nigeria, African Journal of Reproductive Health 10(3), 2006, 55. http://www.ajol.info/index.php/ajrh/article/viewFile/7899/13886 (accessed June 24, 2012); 13. Ijadunola M.Y, Abiona T. C, Ijadunola K. T, Afolabi O. T, Esimai, O. A and OlaOlorun F. M, Male Involvement in Family Planning Decision Making in Ile-Ife Osun State Nigeria, African Journal of Reproductive Health 14(4), $2010,46$. http://www.ajol.info/index.php/ajrh/article/viewFile/67833/55928 (accessed June 24, 2012); 1O.A. Adeleye, O.A. Akoria, Z.O. Shuaib and O.D. Ogholoh, Barriers and Knowledge of Benefits regarding Family Planning Methods among Women attending Antenatal Clinics in a Southern Nigerian Community, Asian Journal of Medical Sciences 2(4), 2010, 193. http://maxwellsci.com/print/ajms/v2-190-194.pdf (accessed June 25, 2012).

[40]. Abidemi R. Asiyanbola, Patriarchy, Male Dominance, the Role and Empowerment of Women in Nigeria, Paper submitted for presentation as poster at the International Union for the Scientific Study of Population (IUSSP/UIESP) XXV International Population Conference Tours, France, 2005, 18-23. http://demoscope.ru/weekly/knigi/tours 2005/papers/iussp2005s50005.pdf (accessed June 24, 2012); Titilayo Cordelia Orisaremi and Ogoh Alubo, Gender and Reproductive Rights of Tarok Women in Central Nigeria, African Journal of Reproductive Health 16(1), 2012, 84. http://www.ajol.info/index.php/ajrh/article/viewFile/75952/66444 (accessed June 24, 2012).

[41]. I. O. Orubuloye, F. Oguntimehin and T. Sadiq, Women's Role in Reproductive Health Decision Making and Vulnerability to STD and HIV/AIDS in Ekiti, Nigeria, Health Transition Review (Supplementary to 7), 1997, 329, 331. http://htc.anu.edu.au/pdfs/Orubulo8.pdf (accessed June 24, 2012).

[42]. Ibid.

[43]. O. A. Moronkola, M. M. Ojediran and A. Amosu, Reproductive Health Knowledge, Beleifs and Determinants of Contraceptive Use among Women attending family Planning Clinics in Ibadan, Nigeria, African Health Sciences 6(3), 2006, 156. http://www.ncbi.nlm.nih.gov/pmc/articles/PMC1831883/pdf/AFHS0603-0155.pdf (accessed June 24, 2012).

[44]. Jonathan S. Maiangwa, An Overview of Pseudo-Therapeutic Approaches to Poverty in Nigeria, African Journal of Political Science and International Relations, 3(9), 2009, 346. http://www.academicjournals.org/ajpsir/pdf/Pdf2009/September/Maiangwa.pdf (accessed June 25, 2012).

[45]. Adeyemi E.O, Waziri, B.A, Atere A.A and Amoo Emmanuel, Economic Reforms, Living Condition and Urban Violence: A Situation Report of Metropolitan Lagos, Ethiopian Journal of Environmental Studies and Management, 2(2), 2009, $37,39$. http://www.ajol.info/index.php/ejesm/article/viewFile/45918/32325 (accessed June 25, 2012); UNITED NATIONS CHILDREN'S FUND (UNICEF), The Nigerian Situation: 2007, http://www.unicef.org/nigeria/1971_2199.html (accessed November 23, 2008). 
[46]. Rand D. Conger, "The Effect of Poverty and Economic Hardship across Generations" being a report prepared for California Department of Social Services, California, 2005, 1. http://cppr.ucdavis.edu/pdf/poverty and hardship.pdf (accessed June 25, 2012).

[47]. Helen Nene Avong, Perception of and Attitudes Towards Nigerian Population Policy, Family Planning Program and Family Planning in Kaduna State Nigeria, African Reproductive Health 4(1), 2000 , http://www.ajol.info/index.php/ajrh/article/viewFile/7722/13856 (accessed June 25, 2012).

[48]. Fiona Samuels, Maja Gavrilovic, Caroline Harper and Miguel Niño-Zarazúa, Food, Finance and Fuel: The Impact of the Triple F Crisis in Nigeria with Particular Focus on Women and Children, Overseas Development Institute, 2011, 4-5. http://www.odi.org.uk/resources/docs/7359.pdf (accessed May 12, 2012)

[49]. Anna Lekas Miller, Occupy Nigeria: The Beginning of Sub-Saharan Awakening, Global Comments, January 14, 2012, http://globalcomment.com/2012/occupy-nigeria-the-beginning-of-a-sub-saharan-awakening/ (accessed May 12, 2012).

[50]. John Mirowsky and Catherine E. Ross, Economic Hardship across the Life Course, American Sociological Review 64, $1999,548$. http://www.jstor.org/discover/10.2307/2657255?uid=3738672\&uid=2\&uid=4\&sid=21100870863291 (accessed June 25, 2012). 